\title{
DESCRIPTION OF WORKING ENVIRONMENT SANITATION IN THE OFFICE BUILDING OF THE WARSHIP DIVISION PT PAL INDONESIA (PERSERO)
}

\author{
Anisa Nur Afifah ${ }^{1}$, Khuliyah Candraning Diyanah ${ }^{1}$ \\ ${ }^{1}$ Department of Environmental Health \\ Faculty of Public Health, Airlangga University, Surabaya, Indonesia \\ Correspondence Address: Anisa Nur Afifah \\ E-mail: anisa.nur.afifah-2015@fkm.unair.ac.id
}

\begin{abstract}
Sanitation is a public health effort that emphasizes mastery of various environmental factors that affect the degree of human health. Agencies that have a good and comfortable work environment will support improved performance for their employees. This study aimed to identify the description of working environment sanitation in the warship division office building at PT PAL INDONESIA (PERSERO). This research was observational. From the entire office space in the Warship Division, the five rooms with the most employees were selected for this research. The research instrument was an observation sheet with variables of building facilities, water supply, toilet, disease vector, lighting, noise, temperature, and humidity. Data analysis was performed descriptively with scoring. The results showed that four out of the five rooms $(80 \%)$ that were observed had poor sanitation because they had a score of less than $75 \%$. The results showed that the variables that were included in the criteria of lack of sanitation were toilets, lighting, temperature, and humidity. Suggestions given for the company are for building facilities, water supply, noise, and disease vector to be maintained because they are included in good sanitation criteria. Toilets, lighting, temperature, and humidity need to be fixed immediately, and reported to the officer responsible if things that can reduce the quality of office sanitation are observed.
\end{abstract}

Keywords: sanitation, indoor air quality, work environment

\section{INTRODUCTION}

The degree of human health is influenced by public health efforts that focus on environmental factors. There are four factors that affect the degree of public health, namely behavioral, environmental, healthcare, and genetic factors (Soejoeti, 2005). Environmental factors in a broad sense include the socio-cultural environment, physical environment, and biological environment. Poor environmental conditions can cause health problems, both physically and mentally (Dharmayanti, et al., 2018). An office is a one story or two story building that is used as a place for employees to do work activities (Indonesian Ministry of Health, 2016a). Economic activities are carried out in office buildings. The main activities in offices are information processing and provision based on information and management activities. These conditions require various sizes of office space based on organizational structure, technology, and management. Regulations regarding office sanitation can be found in the Indonesian Ministry of Health Regulation Number 48 of 2016 regarding Health and Safety Standards in Offices, which include building facilities, water accessibility, toilets, vectors and disease-carrying animals, noise, lighting, temperature, and humidity.

Mangkunegara (2005) stated that a comfortable and good work environment will support the development of employee achievements. According to Handoko (2008), the work environment is a factor that can influence employee performance, where employees can be encouraged to work harder in a good and comfortable work environment. Organizational goals can be achieved if the environment where the employee works is adequate and employees feel motivated and satisfied.

Based on the results of Basic Health Research in 2007, there was a prevalence of 
employee injuries of $7.5 \%$ which continued to increase to $8.2 \%$ in 2013. Around $94.6 \%$ of the prevalence of injuries occurred due to negligence of employees themselves according to data from Basic Health Research in 2013. Sanitation in work environments that does not meet the requirements and pollutants in the form of chemicals can cause a health disorder called Sick Building Syndrome or SBS (Ruth, 2009).

SBS symptoms are not specific or clear enough to be recognized most of time. They are not even categorized as serious symptoms until further treatment or hospital care are needed. Symptoms or complaints can only be felt at the time of entering the building workplace or office and disappear on Sundays or holidays. Symptoms or complaints more often occur in employees who are under pressure and feeling stressed, with less attention and ability to change their situation of employment or livelihood. Some symptoms or complaints of SBS are headache, dry esophagus, eye irritation (red eyes, stinging, itching), loss of concentration, skin irritation, sinusitis, shortness of breath, fast drowsiness, coughing, sneezing, respiratory infections, and stomachache (Yulianti, Ikhsan, and Wiyono, 2012).

The warship division building of PT PAL INDONESIA (PERSERO) is located across many indoor and outdoor areas. This is caused by its location being right in the center of the company's industrial area. The warship division alone has a large indoor workshop building located right beside the office building. The workshop building is divided into four working areas, each having a specific usage.

Although there has not been a case regarding SBS in the warship division building, prevention efforts still need to be made. Steps that can be taken to prevent the occurrence of SBS can begin from the planning of the construction of a building that will be used for a particular activity or work, the layout of equipment in the building to the way equipment are operated, and the selection of building materials such as building foundations, floors, walls, types wall paint, and room dividers. Based on the description above, this study aimed to identify the work environment sanitation in the warship division of the PT PAL INDONESIA (PERSERO) building.

\section{METHODS}

The type of research in this study was observational. From the workplace structure housing the warship division, the five office rooms that had the most employees were Support Department Room, Paint Workshop Head Room, Ekasistrol Workshop Head Room, Electro Outfitting \& Interior Department Bureau Room, and Department Room Machinery Outfitting and Hull Outfitting. Data collection was carried out in January 2019. Measurements were made for variables such as lighting, noise, temperature, and humidity using a 4-in-1 environment meter. For other variables such as water accessibility, vectors and disease-carrying animals, toilets, and building facilities, observations were made with instruments compiled based on the Indonesian Ministry of Health Regulation Number 70 of 2016 regarding Health Standards and Terms in Industrial Workplaces and Regulation Number 48 of 2016 regarding Health and Safety Standards in Offices. Once measured and observed, results were compared with these standards.

Data analyzing was done descriptively using scoring on each variable studied. The weighting was based on the effect of these variables on office environmental sanitation. The greater the weight given, the greater the level of importance of a variable. Assessment was done by classifying requirements in accordance with regulations into eight variables of environmental sanitation in the office. Each requirement had its own value, seen from the influence of each condition. The value of the requirements was multiplied by the weight of the variable to 
obtain a score. With the scores obtained, the criteria for each office space was determined by looking at the percentage obtained. If the score obtained was more than or equal to $75 \%$ of the maximum score, then the office space was considered good. However, if the office space had a score of less than $75 \%$ of the maximum score, then it was considered lacking. The analyzed data was then displayed in the frequency distribution table.

For example, in the water accessibility variable, there were three values which were availability of clean water, clean water quality, and clean water distribution. Each one of them had their own value, respectively, 4, 4, and 2 . The weight of water accessibility weight was 5 , and each value was multiplied with variable weight and the result of each value multiplied with variable weight was totaled. If one value was not fulfilled in an office room observed, then the value was counted as 0 .

The same went for measureable variables such as noise, lighting, temperature, and humidity. If one variable was below the standard based on the Indonesian Ministry of Health Number 70 of 2016 about the Health Standards and Terms in Industrial Workplaces, then that variable was considered not qualified. A variable that was qualified could be valued at 3 and a variable that was not qualified was valued at 1 . The weight in each variable (noise, lighting, temperature, humidity) was different, at 5, 5, 4, and 3, respectively. For the final score, measureable variable and observable variable were totaled, and if they were more than $75 \%$ of the maximum score, the office room was considered in good condition. This study has passed the ethical review at the Faculty of Dentistry at Universitas Airlangga ethics commission with certificate number 433/HRECC.FODM/VII/2019.

\section{RESULTS}

The observation result of building facilities in the work environment of the warship division office building

Table 1. Observational Result Frequency Distribution of Building Facility, Water Accessibility, Toilet, and Vectors in the Warship Division Office at PT. PAL Indonesia

\begin{tabular}{|c|c|}
\hline \multirow[b]{2}{*}{ Variable } & Number of Rooms \\
\hline & $\begin{array}{cc}\text { Lacking } & \text { Good } \\
(\text { score }<75 \% \text { total }) & (\text { score }>75 \% \text { total })\end{array}$ \\
\hline Building Facility & 4 \\
\hline Water Accessibility & 5 \\
\hline Toilet & 5 \\
\hline Vectors & 2 \\
\hline $\begin{array}{l}\text { In the building facilities variable, } \\
\text { there were six conditions. These } \\
\text { requirements were the condition of } \\
\text { buildings, floors, walls, wall surfaces, } \\
\text { ceilings, and vents. From the results of } \\
\text { observation, } 5 \text { of the } 6 \text { requirements had } \\
\text { been met in all rooms. Only one condition } \\
\text { was not yet fulfilled, namely the condition } \\
\text { of ceiling. In accordance with Decree of the } \\
\text { Minister of Health Number } \\
\text { 1405/Menkes/SK/XI/2002 concerning }\end{array}$ & $\begin{array}{l}\text { Health Requirements for Office and } \\
\text { Industrial Work Environments, ceilings in } \\
\text { office spaces must be strong, clean, bright } \\
\text { in color, and at least } 3 \text { meters above the } \\
\text { floor. Table } 1 \text { shows only two rooms met } \\
\text { these requirements of the five rooms that } \\
\text { were observed. This room was Head of } \\
\text { Paint Workshop and Support Department } \\
\text { Room. The other three rooms had ceilings } \\
\text { that were not } 3 \text { meters above the floor, and }\end{array}$ \\
\hline
\end{tabular}


were in a less robust and less clean condition.

The observation result of water accessibility in the work environment of the warship division office building

For the water accessibility variable, all rooms already met all the requirements. These requirements were the availability of clean water, clean water quality, and clean water distribution. All rooms had easy access to clean water, making it easier for employees when needed. The availability of clean water was adequate for hygiene and sanitation activities for all employees. This is very good considering the importance of water availability for the needs of employees. The supply of clean water at PT PAL INDONESIA (PERSERO) itself is supported by the Bangkalan Regional Drinking Water Company (PDAM) to guarantee its quality. The physical quality criteria of water at PT PAL INDONESIA (PERSERO) which includes odor, color, turbidity, and taste had also met the requirements based on the Indonesian Ministry of Health Regulation Number 48 of 2016 regarding Health and Safety Standards in Workplaces. Water distribution mostly used piping systems.

The observation result of toilets in the work environment of the warship division office building

The toilet variable had three conditions, namely separate toilet, number of toilets, and toilet cleanliness. All rooms had one toilet inside to allow employees to easily access them if they need a toilet. Table 1 shows from the five rooms that were observed, all rooms had maintained their cleanliness. The amount was also in accordance with the requirements. However, of the three conditions, there was one condition that was not met in any of the toilets observed. The requirement was that there were no separate toilets between men's and women's toilets. According to Attachment IB to the Circular of the Minister of Public Works No. 12/Se/M/2011 concerning Guidelines for Office and Housing Wastewater Management in the Ministry of Public Works, toilet facilities in offices must be separate between women's and men's toilets.

The observation result of vector in the work environment of the warship division office building

The variable of the presence of disease vectors in each room was not apparent, but there was still a sign of its presence. The results of observations in each room varied greatly. Table 1 shows 3 out of 5 rooms had met the requirements. However, two other rooms were still found to be vectored. In Paint Workshop Headroom there were still cockroaches, in Department Room Machinery Outfitting \& Hull Outfitting there were still cockroaches and rats, while Ekasistrol Workshop Headroom still had cockroaches. The Department Bureau Room Electro Outfitting \& Interior still had cockroaches and rats and the Support Department Room still had rats.

Tabel 2. Observational Result Frequency Distribution of Noise, Lighting, Temperature, Humidity in the Warship Office Building at PT. PAL Indonesia

\begin{tabular}{lcc}
\hline & \multirow{2}{*}{ Variable } & \multicolumn{2}{c}{ Number of Rooms } \\
\cline { 2 - 3 } & Lacking & Good \\
\hline Noise & - & 5 \\
\hline Lighting & 5 & - \\
\hline Temperature & 4 & 1 \\
\hline Humidity & 1 & 4 \\
\hline
\end{tabular}




\section{Noise measurements result in work environment of the warship division office building}

For noise variables, measurements were carried out every 15 seconds for 5 minutes at each noise point source with a distance of 2 meters, then the numbers listed on the screen were recorded and averaged at each point. The condition of the office space in the warship division at the time of measurement, there was little light in the workshop beside the office room. Table 2 shows that all office rooms had qualified noise levels equal to 55-65 dBA with the calculation of working hours of 8 hours per day. This is the effective duration of exposure noise received by the ear (organ of hearing), which should be within a certain amount of time that is not allowed to be surpassed by employees who do not wear protective equipment for ears. The highest average noise level of all five rooms was in Department Bureau Room Electro Outfitting \& Interior at around 58.6 dBA. Noise was expected to originate from the noise of workers' activities in the workshop beside the office room and from outside of the warship division building. Although the work done is not heavy, it still causes noise. Noise is usually sourced from several activities such as heavy equipment removal, welding, and ship repair.

\section{Lighting measurements result in work environment of the warship division office building}

The condition of the office space in the warship division at the time of measurement was there was little light in the workshop beside the office room. According to SNI (2004), if the area of a room is less than $10 \mathrm{~m}^{2}$ then the horizontal cut point width and length should have a distance of $1 \mathrm{~m}$. Whereas if the area of the room is between $10 \mathrm{~m}^{2}-100 \mathrm{~m}^{2}$, the horizontal intersection point should have a width and length at a distance of 3 meters.

Table 2 shows that out of the 5 rooms measured, none met the requirements. There were two rooms that had a lighting level of more than 200, namely Office of the Head of the Ekasistrol Workshop and Departmental Bureau Room Electro Outfitting \& Interior with indoor lighting result which were at 215 lux and 224 lux, respectively. For the other three rooms, the lighting levels were far below the requirements.

\section{Temperature measurements result in work environment of the warship division office building}

The warship division office building had an area of $34,000 \mathrm{~m}^{2}$. There was only minimal lighting in the rooms at the time of measurement. Temperature measurements were carried out in the five office rooms in the warship division.

Table 2 shows the results of measurements of the temperature variable, out of all five rooms, there was only one room that met the standards, which was the Support Department Room at $25.2^{\circ} \mathrm{C}$. The other four rooms' temperature were all above $26^{\circ} \mathrm{C}$.

\section{Humidity measurements result in work environment of the warship division office building}

There was little light work in the workshop in the warship division at the time of measurement beside the office room. Measurement of temperature and humidity was carried out in five office rooms in the warship division.

Table 2 shows the results of the measurement of humidity variables showing that 3 out of 5 rooms did not meet the requirements because the humidity measurement results exceeded $60 \%$. Only two rooms met the standards, namely the Machinery Outfitting \& Hull Outfitting office room $(46.3 \%)$ and the Electro Outfitting \& Interior office room (57.3\%).

\section{DISCUSSION}

After observation and measurements were done, it can be said that 
sanitation of the office work environment of the warship division at PT PAL INDONESIA (PERSERO) was still lacking. Some variables met the requirements, but there were still many variables that need to be improved. Variables that met the requirements in all sample rooms included building facilities, the accessibility of clean water, noise, and the presence of vectors. Meanwhile, the variables that still needed to be increased included toilets, lighting, temperature, and humidity.

\section{Building facilities description in work environment of the warship division office building}

In the Support Department room , floor and wall conditions were still inadequate. From a maximum score of 60 , the room only received a score of 30 , which means only 3 of the 6 requirements had been met. Requirements that were met were the condition of the building, ceiling, and ventilation. While the requirements that were not met were the condition of the floor, walls, and wall surfaces. In the Support Department Room, the floor was still found to be damaged, with tiles that were not properly installed and cracked.

Floors that are not in good condition can cause workplace accidents such as slipping or tripping caused by uneven floor surfaces. The condition of the walls and wall surfaces in the Support Department room also still did not meet the requirements, which are flat and in clean condition. Walls and wall surfaces in this room were uneven and in unsanitary conditions. Damaged wall conditions can interfere with employee productivity because they are in a condition that can jeopardize safety.

Office spaces should have a good, level, and undamaged floor. The walls of an office space should also be flat and clean. If an office space is found to be damaged, it must be repaired immediately to avoid problems. Poor building conditions will affect employee productivity and increase the likelihood of work accidents (Wahyuni, 2018).

Buildings that have stood for decades will experience a decline in the quality of the building, both structural and non-structural. This happens because the building experiences a damaged phase from light damage, medium damage, and total damage from the building's purpose of usage. If the building can be functionally used, then the building requires maintenance to minimize the risk of building users. According to Regulation of the Minister of Public Works Number 24 of 2008 concerning Guidelines for the Maintenance and Maintenance of Buildings, building or building maintenance can maintain the function of the building properly along with the facilities and infrastructure inside it (Ministry of Public Works and Public Housing of the Republic of Indonesia, 2008).

\section{Accessibility of clean water description in work environment of the warship division office building}

Fulfilling all the requirements in the water supply variable is very important for PT PAL INDONESIA (PERSERO), which includes the availability of sufficient water, the quality of water that meets the requirements, and the distribution of water with a piping system. Water is a basic human need that is used every day in all aspects of life. Without adequate water availability, employees would feel uncomfortable at work. Employee inconvenience can result in decreased productivity.

Clean water conditions will greatly support the achievement of good office environmental sanitation and qualified personal hygiene. If there is abundant water but it is not balanced with good water quality, it will be in vain. Good water quality indicates that PT PAL INDONESIA (PERSERO) has paid attention to the basic needs of their employees. The availability of water in PT PAL INDONESIA 
(PERSERO), especially in the warship division, is sufficiently supported by Regional Drinking Water Company (PDAM).

The distribution of water with the piping system also facilitates access to clean water throughout the warship division. The piping system greatly facilitates employees to access clean water at PT PAL INDONESIA (PERSERO). If needed, clean water could be easily found. Employees' needs for clean water vary greatly, such as for washing hands, washing faces, and doing ablution.

Water is a substance that must exist in human life. Humans need water in their daily lives for cooking, drinking, bathing, and washing. According to the WHO, every human being in developed countries needs 60-120 liters of water per day. For developing countries, like Indonesia, each human needs about 30-60 liters of water per day (Mubarak, 2009).

Water that is a part of the environment will give and get an impact from other parts of the environment. If water has poor quality, it can cause environmental conditions to be less sanitary and that can affect health conditions. Water-borne disease is a term for diseases with way of transmission through lack of sanitary water conditions, such as skin diseases, diarrhea, and conjunctivitis.

\section{Toilets description in work environment of the warship division office building}

All rooms were considered unqualified and ineligible for office work environment sanitation requirements because they did not have separate toilets for men and women. No separate toilet between men and women could be caused by limited building area or space. At the time of building construction, toilets were not separated between men and women. This could be improved when building renovations are carried out. It is better if in renovation planning, toilets can be separated between men and women.
Some provisions regarding toilets that must be fulfilled include the condition of the toilet floor, which should always be clean with no pool of water, availability of clean water and soap, no dirt, insects, cockroaches, or rats, cleaned regularly through general and deep program cleaning (Indonesian Ministry of Health, 2016a).

The condition of clean toilets will increase the comfort of employees while in the work environment because they do not have to worry about feeling uncomfortable when they go to the toilet. However, women and men each have different needs while in the toilet. By not separating the toilets between women and men, it can cause discomfort for both parties. This can reduce the feeling of comfort and interfere with employee concentration.

\section{Disease-carrying animals and vectors description in work environment of the warship division office building}

The existence of vectors and disease-carrying animals shows that control of vector and disease-carrying animals have not been carried out optimally. The existence of vectors and disease-carrying animals may be influenced by the old age of buildings, allowing many vector and disease-carrying animals to nest over time. Proper and consistent control of vector and disease-carrying animals can reduce or even eliminate them as a whole. Control can be done in accordance with vectors and disease-carrying animals.

According to Soemirat (2005), the spread of the disease agent can be facilitated by the presence of disease vectors. This proves that the health of the local community can be adversely affected by the entry of new agents. Physical and mechanical vector control methods are an effort to prevent, reduce, and eliminate breeding habitats and vector populations in a physical and mechanical way. Control methods using biotic agents and chemical control methods are based on the Indonesian Ministry of Health Regulation 
Number 374 of 2010 regarding Vector Control.

The existence of disease vectors in the office work environment can cause diseases that reduce worker productivity. Animals and disease-carrying vectors in the work environment must be controlled to prevent health problems and diseases. There are simple procedures that can be done in controlling vectors and diseasecarrying animals such as maintaining environmental cleanliness, for example by cleaning the environment routinely, arranging equipment and records well and neatly, not leaving food in the work environment, and disposing garbage regularly.

\section{Noise description in work environment of the warship division office building}

All rooms met the noise level requirements, which was 55-65 dBA with the calculation of working hours for 8 hours per day. The highest average noise level of the five rooms was in the Electro Outfitting \& Interior Room at 58.6 dBA.

The definition of noise is a sound or noise that is not wanted and can harm or interfere with employees' health. Humans can hear sounds within the $16-20,000 \mathrm{~Hz}$ frequency and intensity with a threshold value of $65 \mathrm{dBA}$ for a prolonged period. Sound or noise intensity of more than 65 $\mathrm{dBA}$ can cause interference and this limit is called the critical level of intensity . Noise measurements result in the work environment of the warship division office building showing a level of noise or sound that is relatively normal and in accordance with NAB. The noise in all of the warship division office rooms was found to be quite comfortable and safe for the employees' sense of hearing.

According to Sasongko (2000), noise can interfere with discussions or conversations and impact ongoing communication . In addition, noise can also cause several psychological disorders such as anxiety, irritation, and fear. Psychological disorders caused by noise depend on the frequency, intensity, time period, and duration of the occurrence of spectrum complexity of noise and irregular noise. Health problems that arise due to the presence of unwanted noise or sound, include digestive disorders, hearing loss, headaches, stress, decreased work performance, and increased blood pressure, among others (Gunawan, 2001). According to Listaningrum (2011), noise also has an impact in the form of decreased hearing function which can cause progressive deafness.

\section{Lighting description in work environment of the warship division office building}

Out of the five rooms observed, none of the rooms met the requirements based on the Indonesian Ministry of Health Regulation Number 48 of 2016 regarding Health and Safety Standards in Offices noting the standard lighting should be $\geq 300$ lux. There were two rooms that had a lighting level of more than 200 lux, namely Head of Workshop Ekasistrol room and Bureau Department Electro Outfitting \& Interior room with each indoor lighting level at 215 lux and 224 lux, respectively. For the other three rooms, the lighting levels were far below the standard.

Lighting has a very significant role in the architecture of buildings, both in creating security and comfort for users of the room, as well as supporting the use of space and the various activities in the space and forming aesthetic visual images (Manurung, 2009). Inappropriate lighting that is too bright or too dark can prevent people in a room from seeing the source of the danger clearly or become slow in recognizing the danger, thus making them unable to see things clearly (Tarwaka, 1998).

Lighting that is far below the determined standards can have bad results in both long and short term. In the short term, inappropriate lighting levels will cause eyestrain and reduce concentration and hinder employees' work. Declining 
concentration will have an impact on employees' productivity in completing work. In the long run, inappropriate lighting will reduce the function of vision organ (Padmanaba, 2008)

Natural lighting is an alternative lighting that is environmentally friendly and good for the eyes. According to Yuniar, et al. (2014), lighting that comes from natural sources is influenced by a number of variables, such as the shape and depth of the room, window opening design, visual comfort, and external factors. According to Thojib, Satya, and Alamat (2013), office buildings require appropriate levels of natural light to ensure employees working inside the building can conduct their activities smoothly and have good labor productivity. Leisure visual points can be achieved when the visual comfort is applied optimally, such as through the arrangement of the room's layout in accordance with the lighting distribution and suitability standard design that is recommended. With using natural light, the usage of electricity can be reduced while taking advantage of nature.

\section{Temperature description in work environment of the warship division office building}

The measurements results of the temperature variable from all of the rooms showed only one room that met the standards, namely the Support Department room with a measurement result of $25.2^{\circ} \mathrm{C}$. The other four rooms temperature measurements results were above $26^{\circ} \mathrm{C}$.

The appropriate temperature in the office area can increase the efficiency, effectiveness and productivity of work that is needed to complete the work properly and correctly. If the temperature in the office is not comfortable, such as too high or too low, then work productivity and metabolic processes in employees' body will be affected. High temperatures especially may result in lowering work achievement and the process of thinking. The temperature in the room that is not in accordance with the specified threshold could potentially degrade employees' productivity as well as other things, like disturbing the precision of the brain, slowing employees in decision-making, and instability of emotions.

\section{Humidity description in work environment of the warship division office building}

The measurements results of the humidity variables in 3 out of 5 rooms did not meet the requirements because the humidity measurement results reached more than $60 \%$. Some factors that affect humidity include air velocity, temperature, and heat radiation from the air, which can affect the condition of the human body when releasing or receiving heat from the body.

Conditions with very high temperatures or heat and high humidity can cause a significant reduction in heat from the body due to the evaporation system. This can affect the increased heart rate caused by active blood circulation to meet oxygen demand, and the human body tends to always strive to achieve compatibility between body heat and ambient temperature. Mismatched humidity levels in the office environment will have a negative impact on employee productivity. With a high level of humidity, a room will feel uncomfortable and disturb employees' concentration.

Humidity and temperature are two environmental factors that have an influence on the sense of smell. To overcome the sense of smell sensitivity problem, air conditioning and adequate ventilation needs to be installed to allow air circulation to take place throughout a room. A good air circulation or air fluctuation in a room can reduce or even eliminate bad odor (Suhardi, 2008).

\section{CONCLUSION}

Overall, it can be said that sanitation of the work environment in the warship division at PT PAL INDONESIA 
(PERSERO) is still lacking. Four rooms, namely Machinery Outfitting \& Hull Outfitting room Department, Bureau of EO \& Interior room Department, Head of Workshop Ekasistrol room, and Support Department room had scores that did not reach $75 \%$ of the maximum score of 188 . The one room that exceeded the score for good criteria of work environment sanitation was the room of Cat workshop head. Another room that was close to $75 \%$ of the maximum score or 188 was the Machinery Outfitting \& Hull Outfitting Department room and Departmental Bureau EO \& Interior room with a score of 183, and the Head of Ekasistrol Workshop room with a score of 187.

Suggestions given to the company are to improve the quality of office environment sanitation in the warship division office building at PT PAL INDONESIA (PERSERO), especially for toilet, lighting, temperature and humidity variables. For building facilities, the accessibility of clean water, noise, and the presence of vectors and disease-carrying animals are included in the criteria for good sanitation; therefore, maintenance needs to be correctly and consistently done. Variables that still did not fully meet the requirements such as lighting variables or those that were only partially met such as building facilities, toilet, vector existence, noise level, temperature level, and humidity level are recommended to be immediately improved and repaired to increase worker productivity and prevent accidents and occupational diseases. Employees should immediately report to the officer in charge of the office environment if experiencing or seeing things that can disrupt or reduce the quality of office sanitation around the warship division office building.

\section{REFERENCE}

Dharmayanti, I., Tjandrarinii, D. H., Hidayangsih, P. S., \& Nainggolan, O. (2018). Pengaruh Kondisi Kesehatan Lingkungan Dan Sosial Ekonomi
Terhadap Kesehatan Mental Di Indonesiia. Jurnal Ekologi Kesehatan, 17(2), 64-74.

Gunawan, L. (2001). Hipertensi: Tekanan Darah Tinggi. Yogyakarta: Percetakan Kanisius.

Handoko, T. (2008). Manajemen Personalia Sumber Daya Manusia Edisi Kedua. Yogyakarta: BPFE.

Listaningrum, A. W. (2011). Pengaruh Intensitas Kebisingan Terhadap Ambang Dengar pada Tenaga Kerja di PT Sekar Bengawan Kabupaten Karanganyar. Skripsi. Surakarta: Universitas Sebelas Maret. Jurnal Kesehatan Masyarakat (e-Journal).

Mangkunegara, A. P. (2005). Sumber Daya Manusia Perusahaan. Bandung: Remaja Rosdakarya.

Mubarak, C. (2009). Ilmu Kesehatan Masyarakat Teori dan Aplikasi. Jakarta: Salemba Medika.

Ministry of Health RI. (2016a). Peraturan Menteri Kesehatan Republik Indonesia Nomor 48 Tahun 2016 Tentang Standar Keselamatan Dan Kesehatan Kerja Perkantoran.

Ministry of Health RI. (2016b). Peraturan Menteri Kesehatan Republik Indonesia Nomor 70 Tahun 2016 tentang Standar dan Persyaratan Kesehatan Lingkungan Kerja Industri.

Ministry of Public Works and Public Housing of the Republic of Indonesia. (2008). Standar Pemeliharaan Gedung. Jakarta: Sekretariat Negara $R I$.

Padmanaba, C. (2008). Pengaruh Penerangan Dalam Ruang Terhadap Produktivitas Kerja Mahasiswa Desain Interior. Dimensi Interior, 4(3), 57-63. https://doi.org/https://doi.org/10.9744 /interior.4.2.pp.\%2057-63

Ruth, S. (2009). Gambaran Kejadian Sick Building Syndrome (SBS) dan FaktorFaktor yang Berhubungan Pada Karyawan PT Elnusa Tbk di Kantor Pusat Graha Elnusa Tahun 2009.

Sasongko, H. A. (2000). Kebisingan 
Lingkungan. Semarang: Universitas Diponegoro.

Soejoeti, S. (2005). Konsep sehat, sakit dan penyakit dalam konteks sosial budaya. Soemirat, J. (2005). Khomariyatika, T. 2007(1), 14-16.

Suhardi, B. (2008). Perancangan Sistem Kerja dan Ergonomi Industri Jilid 2 untuk SMK. Jakarta: Departemen Pendidikan Nasional.

Tarwaka. (1998). Penerangan Ditempat Kerja. Bali: Balai Hiperkes Dan Keselamatan Kerja.

Thojib, J., Satya, M., \& Alamat, A. (2013). Kenyamanan Visual Melalui Pencahayaan Alami Pada Kantor. Jurnal RUAS, 11(2), 10-15. https://doi.org/http://dx.doi.org/10.21 776/ub.ruas.2013.011.02.2
Wahyuni, D. (2018). Pengelolaan Laboratorium Sekretaris Kompetensi Keahlian Administrasi Perkantoran Di Smk Negeri 1 Yogyakarta. Skripsi. Yogyakarta: Fakultas Ekonomi, Universitas Negeri Yogyakarta.

Yulianti, D., Ikhsan, M., \& Wiyono, W. H. (2012). Sick Building Syndrome. 39(1), 21-24.

Yuniar, E., Dwicahyo, S., Harmanda, S. J., Putra, D. K., \& Wijaya, F. R. (2014). Kajian Pencahayaan Alami pada Bangunan Villa Isola Bandung. Jurnal Reka Karsa @Teknik Arsitektur Itenas Jurnal Online Institut Teknologi Nasional, 2(1), 1-11. https://doi.org/10.26760/rekakarsa.v2i 1.454 